\title{
Formulation of Antimicrobial Tobramycin Loaded PLGA Nanoparticles via Complexation with AOT
}

\author{
Marcus Hill ${ }^{1}$, Richard N. Cunningham ${ }^{1}$, Rania M. Hathout ${ }^{2} \oplus$, Christopher Johnston ${ }^{1}$, \\ John G. Hardy ${ }^{3,4, *(\mathbb{D})}$ and Marie E. Migaud $1,5, *$ (i) \\ 1 School of Pharmacy, Queen's University Belfast, Belfast BT7 1NN, UK; mhill11@qub.ac.uk (M.H.); \\ rcunningham09@qub.ac.uk (R.N.C.); christopher.johnston@qub.ac.uk (C.J.) \\ 2 Department of Pharmaceutics and Industrial Pharmacy, Faculty of Pharmacy, Ain Shams University, \\ Cairo 11566, Egypt; rania.hathout@pharma.asu.edu.eg \\ 3 Department of Chemistry, Lancaster University, Lancaster, Lancashire LA1 4YB, UK \\ 4 Materials Science Institute, Lancaster University, Lancaster, Lancashire LA1 4YB, UK \\ 5 USA Mitchell Cancer Institute, University of South Alabama, Mobile, AL 36604, USA \\ * Correspondence: j.g.hardy@lancaster.ac.uk (J.G.H.); mmigaud@health.southalabama.edu (M.E.M.); \\ Tel.: +1-251-410-4938 (M.E.M.)
}

Received: 3 March 2019; Accepted: 10 June 2019; Published: 13 June 2019

\begin{abstract}
Tobramycin is a potent antimicrobial aminoglycoside and its effective delivery by encapsulation within nanoparticle carriers could increase its activity against infections through a combination of sustained release and enhanced uptake. Effective antimicrobial therapy against a clinically relevant model bacteria (Pseudomonas aeruginosa) requires sufficient levels of therapeutic drug to maintain a drug concentration above the microbial inhibitory concentration (MIC) of the bacteria. Previous studies have shown that loading of aminoglycoside drugs in poly(lactic-co-glycolic) acid (PLGA)-based delivery systems is generally poor due to weak interactions between the drug and the polymer. The formation of complexes of tobramycin with dioctylsulfosuccinate (AOT) allows the effective loading of the drug in PLGA-nanoparticles and such nanoparticles can effectively deliver the antimicrobial aminoglycoside with retention of tobramycin antibacterial function.
\end{abstract}

Keywords: biomedical applications; colloids; drug delivery systems; nanoparticles; antimicrobial

\section{Introduction}

Pseudomonas aeruginosa is an aerobic gram negative bacterium which can survive in a variety of environments [1]. P. aeruginosa infections in immune competent patients tend to arise through physical trauma or surgical complications [2,3]. The majority of serious infections involve patients in which the normal functioning of the immune system has been compromised (e.g., AIDS and cystic fibrosis [4,5]), or cases involving complications caused by the administration of broad spectrum antibiotics which can disrupt the normal protective mucosal flora [6]. P. aeruginosa infection is increasingly prevalent and is responsible for $16 \%$ of nosocomial pneumonia infections, $10 \%$ of bloodstream infections and $8 \%$ of surgical wound infections reported [7].

There is a market need for systems capable of the controllable delivery of hydrophilic drugs [8]. Many drugs have been shown to achieve greater therapeutic efficacy through loading within nanoparticulate drug delivery systems based on their potential for precise targeting and sustained release [9-11]. However, this formulation remains difficult to achieve for highly polar, water-soluble drugs. While the hydrophilicity of a drug can offer advantages including improved bioavailability and absorption [12], this can lead to poor loading within polymer-based nanoparticles if interactions between the drug and the polymer are weak [13]. 
Yet, the formulation of antibiotic-loaded nanoparticles has been applied to address a variety of diseases [14-16], with such formulations showing a number of advantages over conventional administration (including enhanced antibacterial effect and targeting) [17]. The targeted delivery and sustained release of the drug over time permit specific delivery to the diseased site, allowing for the reduction in the frequency of dosing and reduction in the off-site toxicity experienced with certain drugs [18].

Aminoglycosides are a class of drug molecules which are generally prescribed for the treatment of bacterial infections, e.g., to the lungs to treat respiratory conditions $[19,20]$. This family of highly polar drugs shares a similar chemical scaffold although subtle spatial and functional group changes lead to differences in the therapeutic activity of the drug [19]. Tobramycin (Figure 1) is most commonly prescribed for the treatment of infections with P. aeruginosa [21]. Its antibacterial activity is mediated through binding to the $30 \mathrm{~s}$ ribosomal subunit in gram negative bacterial strains [22], while rapid efflux is accomplished by phosphorylation [23-25]. The incorporation of aminoglycoside drugs within PLGA-based carriers has previously proven challenging [26] due to the lack of complementary polar groups on the backbone of PLGA to interact with the aminoglycosides (i.e., weak polymer-drug interactions) [27]. Furthermore, non-aqueous solvents are commonly required for the formation of the nanoparticles. These often prove to be poor solvents for the aminoglycosides and therefore a limiting factor in the formulation process.

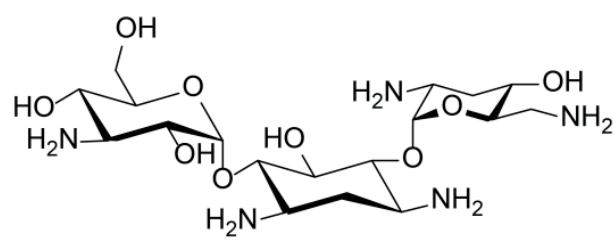

A

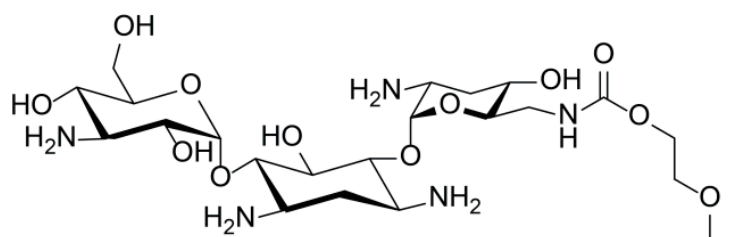

B<smiles>CCCCC(CC)COC(=O)CC(C(=O)OCC(CC)CCCC)C(=O)OS(N)(=O)=O</smiles>

C

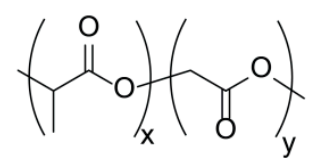

D

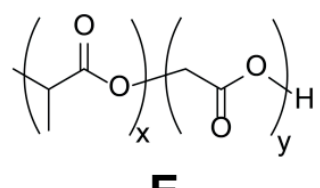

Figure 1. Chemical structures investigated in this report. (A) Tobramycin; (B) Fluorescent tobramycin derivative; (C) dioctylsulfosuccinate (AOT); (D) PLGA 503 ester terminated; (E) PLGA 502H acid terminated.

Alternative solvents can be employed to improve the loading of hydrophilic drugs within hydrophobic polymers (e.g., supercritical fluids) [28]. However, this relies upon the co-dissolution of the drug and the polymer within the supercritical fluid which remains challenging [29].

Poly-lactic-co-glycolic acid (PLGA) has been utilised for a variety of sustained release drug delivery systems [30-32], for example, the aminoglycoside antibiotic gentamicin [33]. Studies have shown that the incorporation of such drugs in PLGA nanoparticles can offer enhanced therapeutic benefit in biological models of disease [34]. However, the overall loading of the hydrophilic drugs can limit the therapeutic benefit because of weak polymer-drug interactions $[35,36]$. This observation motivates the investigation of methods that can increase polymer-drug interactions with the view of enhancing the level of drug-loading within the nanoparticles. Chemical modifications of the drug can enhance polymer-drug interactions while also retaining the activity of the drug [37]. An alternative 
approach is the co-formulation with a surfactant [38], which was used successfully for the preparation of liposomal formulations of tobramycin to treat infections with P. aeruginosa [39-43].

The anionic surfactant AOT is FDA approved for human therapy [44] and has been used to extract various hydrophilic drugs and proteins into organic media [45-47]. To facilitate the detection of non-chromophoric drugs in the aqueous media, we prepared a fluorescent tobramycin derivative, and here we report the results of our studies investigating the co-formulation of non-chromophoric tobramycin and AOT, enabling its encapsulation within, and release from, PLGA nanoparticles (including a comparison of the constitutional and electronic physical descriptors of tobramycin, the fluorescent tobramycin derivative and their AOT-complexes [48,49]). The PLGA-based nanoparticles delivered tobramycin from the PLGA nanoparticles to the clinically relevant model bacteria (P. aeruginosa) at levels above the microbial inhibitory concentration (MIC) of the bacteria.

\section{Results and Discussion}

\subsection{Tobramycin Formulation}

The uptake efficiency of tobramycin by PLGA is governed by drug-polymer interactions. We evaluated two forms of PLGA: PLGA RG502H and PLGA RG503. PLGA RG502H is more hydrophilic and was previously shown to trap hydrophilic drugs more efficiently [33]. PLGA nanoparticle production has been the subject of many investigations and excellent reviews [50,51]. In this study we formulated nanoparticles using water-in-oil-in-water (w/o/w) emulsion [52] and solid-in-oil-in-water $(\mathrm{s} / \mathrm{o} / \mathrm{w})$ emulsion [53] methodologies, and their properties and tobramycin loading are reported in Table 1. Both methodologies resulted in loading of tobramycin within the nanoparticles (albeit relatively low concentrations of drug in the particles). We observed that the $\mathrm{w} / \mathrm{o} / \mathrm{w}$ formulation methodology resulted in the generation of smaller particles (determined by Dynamic Light Scattering, DLS) than the s/o/w methodology, and that the s/o/w methodology also resulted in higher levels of tobramycin loading; and as expected the nanoparticles generated from the more hydrophilic PLGA derivative (RG502H) had a moderately higher zeta potential and drug loading (although this was not statistically significant).

Table 1. Particle properties and tobramycin loading achieved with PLGA RG502H and RG503 nanoparticles with the $\mathrm{S} / \mathrm{O} / \mathrm{W}$ and $\mathrm{W} / \mathrm{O} / \mathrm{W}$ formulation strategies.

\begin{tabular}{ccccccc}
\hline $\begin{array}{c}\text { PLGA } \\
\text { Derivative }\end{array}$ & Formulation & $\begin{array}{c}\text { DLS } \\
\text { Particle Size } \\
(\mathbf{n m})\end{array}$ & PDI & $\begin{array}{c}\text { Zeta Potential } \\
(\mathbf{m V})\end{array}$ & $\begin{array}{c}\text { Tobramycin Loading in } \\
\text { PLGA Nanoparticles } \\
(\boldsymbol{\mu g} / \mathbf{m g})\end{array}$ & \% Loading \\
\hline RG503 & w/o/w & $267.4 \pm 5.3$ & $0.14 \pm 0.02$ & $-7.8 \pm 2.2$ & $2.7 \pm 0.4$ & $4.5 \pm 0.7$ \\
RG502H & w/o/w & $259.8 \pm 6.8$ & $0.18 \pm 0.04$ & $-9.6 \pm 3.2$ & $3.9 \pm 0.3$ & $6.5 \pm 0.5$ \\
RG503 & s/o/w & $345.8 \pm 17.2$ & $0.16 \pm 0.08$ & $-8.2 \pm 2.8$ & $3.4 \pm 0.7$ & $5.7 \pm 1.2$ \\
RG502H & s/o/w & $364.8 \pm 22.4$ & $0.22 \pm 0.11$ & $-9.4 \pm 3.3$ & $4.4 \pm 0.6$ & $7.3 \pm 1.0$ \\
\hline
\end{tabular}

With a view to increase the loading of tobramycin within the PLGA nanoparticles, we investigated the co-formulation of the drug with a surfactant (AOT) that has previously been used to increase the loading of other hydrophilic drugs within PLGA nanoparticles. This was achieved by increased lipophilicity of the drug-AOT complexes generated through ionic interactions; in this case the anionic sulfonate of the AOT and the cationic amine of tobramycin) [54-56]. To assess the lipophilicity of the tobramycin-AOT complexes, the extraction of tobramycin into organic solvents was assessed by a variety of methods. A fluorescent tobramycin derivative (B) was synthesized (Scheme 1, and Supplementary Information Figures S1-S13) which facilitated the visual observation of its extraction into the aqueous layer of a dichloromethane-water bilayer (Figure 2). 


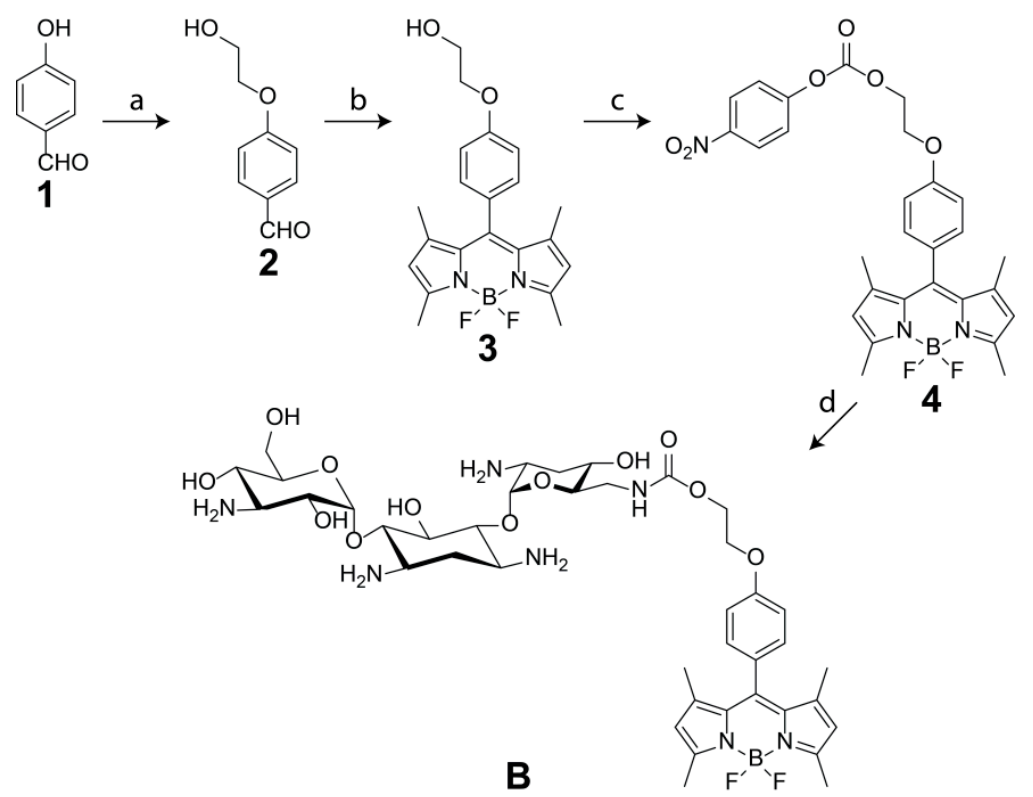

Scheme 1. Synthesis of a fluorescent tobramycin derivative.

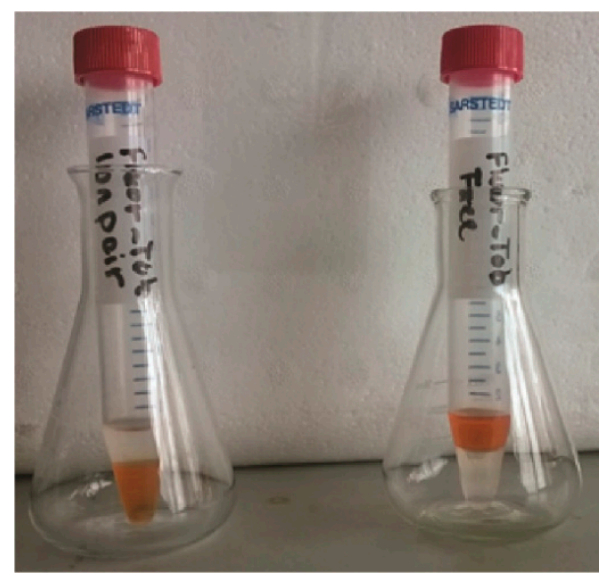

Figure 2. Organic extraction of the fluorescent derivative of tobramycin in the presence (left) and absence (right) of AOT: top layer water, bottom layer dichloromethane.

The physical descriptors (constitutional and electronic) of tobramycin, the fluorescent tobramycin derivative and their AOT-complexes are calculated (Table 2). The selected descriptors were molecular weight, total polar surface area, number of hydrogen bond donors, number of hydrogen bond acceptors, molecular globularity, molecular flexibility and $\log \mathrm{P}(\mathrm{O} / \mathrm{W})[48,49]$.

The significant changes in molecular descriptors upon conjugation of the fluorophore to tobramycin (particularly total polar surface area, molecular globularity, molecular flexibility and the $\log \mathrm{P}(\mathrm{O} / \mathrm{W})$ value) meant that we did not carry out encapsulation or release studies with the fluorescent derivative as it would lead to inaccurate predictions of the encapsulation and release of the non-fluorescent tobramycin, that would be clinically relevant. Consequently, tobramycin extraction into a selection of non-aqueous solvents was quantified by reaction of tobramycin with ortho-phthaldialdehyde and 2-mercaptoethanol and subsequent fluorescence spectroscopy [57] with results displayed in Table 3. In the light of this data and literature precedent [58], we used dichloromethane for the remaining loading experiments. As expected, we observed that the molar ratio of AOT:tobramycin played a role in the extraction of tobramycin into dichloromethane, with complete extraction above a molar ratio of 0.1 AOT:tobramycin (Figure S14). 
Table 2. The physical descriptors (constitutional and electronic) of tobramycin, the fluorescent tobramycin derivative and their AOT-complexes.

\begin{tabular}{cccccccc}
\hline Species & $\begin{array}{c}\text { Molecular } \\
\text { Weight (g/mol) }\end{array}$ & $\begin{array}{c}\text { Total } \\
\text { Polar SA }\end{array}$ & $\begin{array}{c}\text { No. H Bond } \\
\text { Acceptors }\end{array}$ & $\begin{array}{c}\text { No. H Bond } \\
\text { Donors }\end{array}$ & $\begin{array}{c}\text { Molecular } \\
\text { Globularity }\end{array}$ & $\begin{array}{c}\text { Molecular } \\
\text { Flexibility }\end{array}$ & $\begin{array}{c}\text { LogP } \\
\text { (O/W) }\end{array}$ \\
\hline $\begin{array}{c}\text { Tobramycin } \\
\text { derivative }\end{array}$ & 467.520 & 420.078 & 14 & 10 & 0.123 & 9.277 & -6.412 \\
\hline $\begin{array}{c}\text { Fluorescent } \\
\text { tobramycin } \\
\text { derivative }\end{array}$ & 878.756 & 694.379 & 15 & 10 & 0.163 & 12.913 & -1.894 \\
\hline $\begin{array}{c}\text { AOT-Tobramycin } \\
\text { complex }\end{array}$ & 912.085 & 694.379 & 16 & 10 & 0.252 & 29.588 & -1.342 \\
\hline $\begin{array}{c}\text { AOT-Fluorescent } \\
\text { tobramycin } \\
\text { complex }\end{array}$ & 1323.321 & 852.276 & 17 & 10 & 0.218 & 29.376 & -3.176 \\
\hline
\end{tabular}

Table 3. Extraction of tobramycin into non-aqueous solvents in the absence/presence of AOT.

\begin{tabular}{cccc}
\hline Solvent & Dielectric Constant & $\begin{array}{c}\text { \% Extraction in the } \\
\text { Absence of AOT }\end{array}$ & $\begin{array}{c}\text { \% Extraction in the } \\
\text { Presence of AOT }\end{array}$ \\
\hline 2-butanol & 17.26 & $0 \pm 0$ & $90.3 \pm 5.7$ \\
Chloroform & 4.81 & $0 \pm 0$ & $100 \pm 0$ \\
Dichloromethane & 8.93 & $0 \pm 0$ & $100 \pm 0$ \\
Ethyl acetate & 6.02 & $0 \pm 0$ & $100 \pm 0$ \\
Toluene & 2.38 & $0 \pm 0$ & $100 \pm 0$ \\
\hline
\end{tabular}

It was also expected that there would be a $\mathrm{pH}$ dependence on the extraction of tobramycin into dichloromethane. The sulfonic acid of AOT is deprotonated at most $\mathrm{pH}$ values, and we observed that at low $\mathrm{pH}$ values ( $\mathrm{pH} 2$ and 4), the amines displayed on tobramycin were fully protonated and the tobramycin was completely partitioned in the dichloromethane (Figure 3). Above $\mathrm{pH} 5$ we observed some tobramycin remained in the aqueous phase as not all the amines were fully protonated, with only $59 \%$ of the drug extracted into the dichloromethane phase at $\mathrm{pH} 12$.

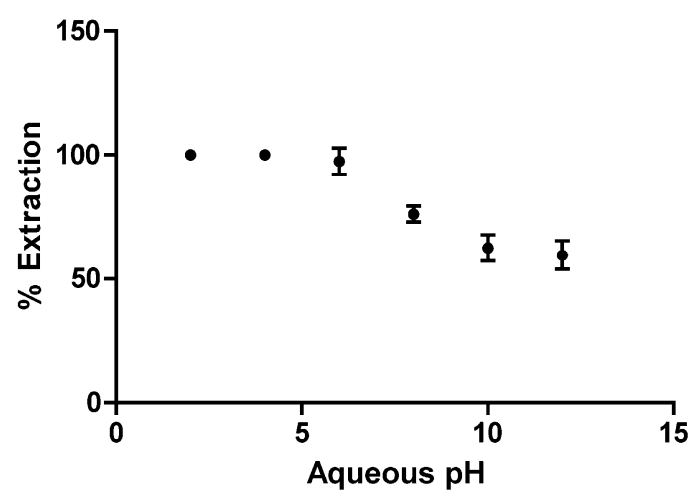

Figure 3. Effect of $\mathrm{pH}$ on the extraction of tobramycin into dichloromethane by AOT.

To assess if the increased solubility of tobramycin in non-aqueous solvents (Table 3, Figures 2 and 3) and the changes in molecular descriptors (particularly molecular globularity, molecular flexibility and the $\log \mathrm{P}(\mathrm{O} / \mathrm{W})$, in Table 2) correlated to increased uptake of tobramycin within the PLGA nanoparticles $[50,59,60]$, we prepared solutions of PLGA nanoparticles from O/W emulsions (with the oil phase composed of solutions of PLGA and tobramycin:AOT complexes in dichloromethane). In contrast to the experiments undertaken in the absence of AOT, the PLGA derivative had no statistically significant effect on the particle properties or tobramycin loading (Table 4). The particle size and zeta potential of the nanoparticles were observed to increase as the concentration of PLGA in the emulsions increased. The zeta potential values of the nanoparticles appeared to be dependent on the 
PLGA derivative, with the PLGA RG502H (carboxyl terminated PLGA chains) particles having lower zeta potential values than PLGA RG503 (methyl ester terminated PLGA chains), although this was not statistically significant. High loading was observed for all the formulations being tested $(>89 \%)$. With a view to sustaining the release of the tobramycin from the particles (with minimal burst release from drug close to the surface of the particles) we chose to use the nanoparticles derived from emulsion formulations containing $30 \mathrm{mg}$ of PLGA RG502H for subsequent experiments.

Table 4. Properties and tobramycin uptake of PLGA RG502H and PLGA RG503 nanoparticles.

\begin{tabular}{cccccc}
\hline $\begin{array}{c}\text { PLGA } \\
\text { Derivative }\end{array}$ & $\begin{array}{c}\text { Mass of } \\
\text { PLGA (mg) }\end{array}$ & $\begin{array}{c}\text { Particle Size } \\
(\mathbf{n m})\end{array}$ & PDI & $\begin{array}{c}\text { Zeta Potential } \\
(\mathbf{m V})\end{array}$ & $\begin{array}{c}\text { Tobramycin Loading in } \\
\text { PLGA Nanoparticles } \\
(\boldsymbol{\mu g} / \mathbf{m g})\end{array}$ \\
\hline RG502H & 10 & $229.4 \pm 21.6$ & $0.23 \pm 0.09$ & $-11.2 \pm 3.1$ & $274.2 \pm 9.6$ \\
\%G502H & 20 & $434.5 \pm 52.5$ & $0.42 \pm 0.11$ & $-11.8 \pm 3.2$ & $96.4 \pm 2.9$ \\
RG502H & 30 & $469.2 \pm 57.2$ & $0.39 \pm 0.06$ & $-12.2 \pm 2.8$ & $57.5 \pm 1.3$ \\
RG503 & 10 & $295.6 \pm 46.4$ & $0.26 \pm 0.10$ & $-8.5 \pm 3.3$ & $269.4 \pm 7.2$ \\
RG503 & 20 & $437.2 \pm 49.6$ & $0.39 \pm 0.07$ & $-9.1 \pm 2.3$ & $96.8 \pm 3.4$ \\
RG503 & 30 & $474.2 \pm 57.2$ & $0.46 \pm 0.14$ & $-9.4 \pm 2.7$ & $57.9 \pm 1.9$ \\
\hline
\end{tabular}

\subsection{In Vitro Tobramycin Release Studies}

As the treatment of chronic infections with P. aeruginosa generally requires prolonged exposure to the antimicrobial for efficient therapy, the sustained release properties of the tobramycin-AOT loaded PLGA RG502H nanoparticles (prepared from emulsions containing $30 \mathrm{mg}$ of PLGA RG502H) were tested (Figure 4). The slightly high rate of tobramycin release over the first few hours was ascribed to the release of tobramycin located close to the surface of the nanoparticles (ca. $10 \%$ of the total load of tobramycin); however, after this initial release from the surface, the internal tobramycin was released at a much slower rate and this over a period of days, with less than half the total payload delivered in 2 weeks (Figure 4) offering potential for use of less drug and lower dosing frequency which would be expected to enhance patient compliance (i.e., economic, environmental, health and societal impacts).

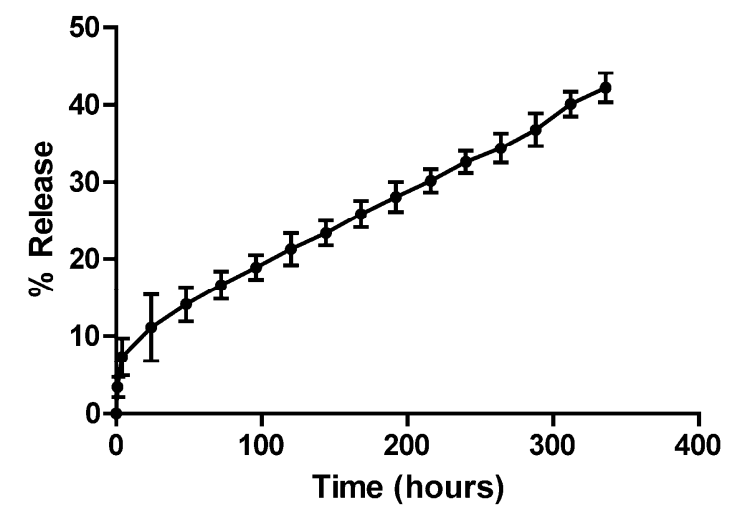

Figure 4. Release profile of PLGA RG502H nanoparticles entrapped with tobramycin loaded AOT reverse micelles at $37^{\circ} \mathrm{C}$ in PBS.

The effect of tobramycin release from the PLGA RG502H nanoparticles loaded with tobramycin-AOT complexes was tested against $P$. aeruginosa (Figure 5). Unloaded PLGA RG502H nanoparticles showed no activity against $P$. aeruginosa (Figure 5A), whereas the free tobramycin showed dose dependent toxicity towards the P. aeruginosa (Figure 5B), with the MIC of the tobramycin at $1.25 \mu \mathrm{g} / \mathrm{mL}$. Importantly, the PLGA RG502H nanoparticles loaded with tobramycin-AOT complexes showed activity in a dose dependent manner (Figure 5C). The MIC of the tobramycin encapsulated in the nanoparticles was shown to be $1.25 \mu \mathrm{g} / \mathrm{mL}$, identical to that of free tobramycin, confirming that no loss of activity was detected following encapsulation. The full release of tobramycin would be achieved over days in the 
absence of cells (Figure 5); however, once internalized in the cells, the release of tobramycin would be likely to be enhanced by enzymatic degradation of the PLGA [61].
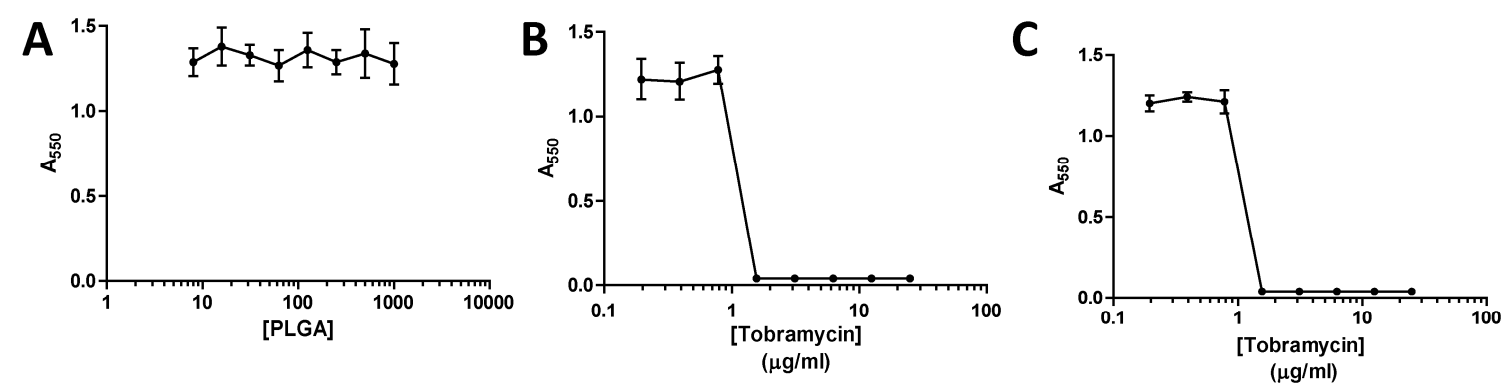

Figure 5. MIC analysis. (A) Unloaded nanoparticle control; (B) Free tobramycin; (C) Tobramycin loaded nanoparticles.

Researchers based in industry and academia have invested significant effort into the development of active ingredient delivery systems. Systems that deliver their payloads at a predetermined rate and control the level of active ingredient within target tissues above the minimum effective level for prolonged periods help to reduce the dosing frequency (and concomitantly problems with patient compliance), which offer economic, environmental, health and societal impacts. There is a market need for delivery systems with sustained release of polar antimicrobials capable of eradicating bacterial growth in patients with weak immune systems [62-68]. Here we describe one method of loading high levels of antimicrobials in PLGA nanoparticles and demonstrate their efficacy against P. aeruginosa in vitro, using transient drug-polymer interactions for encapsulation and slow-release, and we envisage such systems to have potential for the treatment of respiratory infections $[69,70]$.

\section{Materials and Methods}

\subsection{Materials}

Tryptone, sodium chloride (bacteriological grade) and yeast extract were purchased from Oxoid Ltd, Basingstoke, Hampshire, England. Formvar carbon films on copper were purchased from Agar scientific (Stansted, UK). The polymers: PLGA Resomer RG502H (50:50 lactide:glycolide, acid terminated); PLGA Resomer RG503 (50:50 lactide:glycolide, ester terminated); Poly(vinyl alcohol) (PVA), 87-89\% hydrolysed with molecular weight 13-23 KDa; and all other consumables were purchased from Sigma-Aldrich (Gillingham, UK) unless otherwise stated.

\subsection{Preparation of the Fluorescent Tobramycin Derivative and Its Use for Visualisation of Bilayer} Extraction Experiments

\subsubsection{Synthesis of 4-(2-hydroxyethoxy)benzaldehyde}

4-Hydroxybenzaldehyde (1, Scheme 1) (1.50 g, $12.28 \mathrm{mmol}, 1.0 \mathrm{eq})$, 2-bromoethanol (1.31 mL, 18.42 mmol, $1.5 \mathrm{eq})$ and $\mathrm{K}_{2} \mathrm{CO}_{3}(5.10 \mathrm{~g}$, $36.85 \mathrm{mmol}, 3.0 \mathrm{eq})$ were solubilized in DMF (15 mL). The reaction mixture was stirred for $6 \mathrm{~h}$ at $100{ }^{\circ} \mathrm{C}$ and then poured into water $(15 \mathrm{~mL})$ and extracted with chloroform $(3 \times 25 \mathrm{~mL})$. The organic layers were combined and dried over $\mathrm{Na}_{2} \mathrm{SO}_{4}$. The solvent was removed under reduced pressure and purified using biotage column chromatography (Hexane/EtOAc) 6:4) to give $2.15 \mathrm{~g}$ (93\%) of 4-(2-hydroxyethoxy)benzaldehyde as a colorless oil. 1H NMR (400 MHz, CDCl3): $\delta$ ppm $9.89(1 \mathrm{H}, \mathrm{s}, \mathrm{HC}=\mathrm{O}), 7.85(2 \mathrm{H}, \mathrm{d}, \mathrm{J}=9.3 \mathrm{~Hz}, \mathrm{Ar}), 7.03(2 \mathrm{H}, \mathrm{d}, \mathrm{J}=8.7 \mathrm{~Hz}, \mathrm{Ar}), 4.18(2 \mathrm{H}, \mathrm{t}, \mathrm{J}=9.0 \mathrm{~Hz}$, $\mathrm{OCH} 2 \mathrm{CH} 2 \mathrm{OH}), 4.02(2 \mathrm{H}, \mathrm{t}, \mathrm{J}=9.3 \mathrm{~Hz}, \mathrm{OCH} 2 \mathrm{CH} 2 \mathrm{OH}) .13 \mathrm{C}$ NMR $(125 \mathrm{MHz}): \delta \mathrm{ppm} 190.9(\mathrm{HC}=\mathrm{O})$, $163.7(\mathrm{Ar}), 132.0(\mathrm{Ar}), 130.2(\mathrm{Ar}), 114.9(\mathrm{Ar}), 69.6(\mathrm{OCH} 2 \mathrm{CH} 2 \mathrm{OH}), 61.2(\mathrm{OCH} 2 \mathrm{CH} 2 \mathrm{OH}),(\mathrm{ES}) \mathrm{m} / \mathrm{s}:$ C9H10O3: Calculated $[\mathrm{M}+\mathrm{H}]^{+}$189.0528, actual $[\mathrm{M}+\mathrm{H}]^{+}$found 189.0519. 
3.2.2. Synthesis of (3, 5-dimethyl-1H-pyrrol-2-yl)-(tetramethyl-4, 4-difluoro-4-bora-3a, 4a-diaza-indacene) methyl] phenoxy] ethanol

4-(2-Hydroxyethoxy) benzaldehyde (2, Scheme 1) (1.50 g, $0.01 \mathrm{~mol}, 1.0 \mathrm{eq})$ and 2-4-dimethylpyrrole (1.95 mL, $0.02 \mathrm{~mol}$, and $2.0 \mathrm{eq})$ were solubilised in dry DCM $(200 \mathrm{~mL})$ under an atmosphere of $\mathrm{N}_{2}$. TFA (cat) added to the solution and the reaction mixture was left stirring at room temperature overnight. After disappearance of the aldehyde monitored using TLC, a solution of DDQ (2.00 g, $0.01 \mathrm{~mol}$, and $1.0 \mathrm{eq})$ in dry DCM $(5 \mathrm{~mL})$ was added and stirring was continued for $30 \mathrm{~min}$ at room temperature. To the mixture was then added triethylamine $(9.60 \mathrm{~mL}, 0.07 \mathrm{mmol}, 7.6 \mathrm{eq})$ and left stirring for $15 \mathrm{~min}$, after which $\mathrm{BF}_{3} . \mathrm{OEt}_{2}(9.60 \mathrm{~mL}, 0.08 \mathrm{mmol}, 8.6 \mathrm{eq})$ was added drop wise at $0{ }^{\circ} \mathrm{C}$. The stirring was continued overnight; then the solution was concentrated under reduced pressure and purified using biotage column chromatography (DCM/EtOAc) 0-10\%) to yield $0.96 \mathrm{~g}(25 \%)$ of the fluorophore as fine orange needles. 1H NMR (400 MHz, CDCl3): $\delta$ ppm $7.18(2 \mathrm{H}, \mathrm{d}, \mathrm{J}=8.0 \mathrm{~Hz}, \mathrm{Ar}), 7.03(2 \mathrm{H}, \mathrm{d}, \mathrm{J}=8.8 \mathrm{~Hz}, \mathrm{Ar})$, $5.98(2 \mathrm{H}, \mathrm{s}, 2 \times \mathrm{C}=\mathrm{CHC}), 4.15-4.14(2 \mathrm{H}, \mathrm{m}, \mathrm{OCH} 2 \mathrm{CH} 2 \mathrm{OH}), 4.02(2 \mathrm{H}, \mathrm{t}, \mathrm{J}=4.4 \mathrm{~Hz}, \mathrm{OCH} 2 \mathrm{CH} 2 \mathrm{OH})$, $2.55(6 \mathrm{H}, \mathrm{s}, 2 \times \mathrm{CH} 3 \mathrm{CN}) 1.43(6 \mathrm{H}, \mathrm{s}, 2 \times \mathrm{CH} 3 \mathrm{C}=\mathrm{C}) .13 \mathrm{C}$ NMR (125 MHz): $\delta$ ppm 159.3 (Ar), 155.3 (Ar), 143.1 (Ar), 141.7 (Ar), 131.8 (Ar), 129.3 (Ar), 127.4 (Ar), 121.1 (Ar), 115.1 (Ar), 69.3 (OCH2CH2OH), 61.3 $(\mathrm{OCH} 2 \mathrm{CH} 2 \mathrm{OH}), 14.5(2 \times \mathrm{CH} 3 \mathrm{CN}$ and $2 \times \mathrm{CH} 3 \mathrm{C}=\mathrm{C}) .19 \mathrm{~F} \mathrm{NMR}(376 \mathrm{MHz}): \delta \mathrm{ppm}-143.3 \mathrm{ppm}(\mathrm{B}-\mathrm{F} 2, \mathrm{q}$, $\mathrm{J}=31.3 \mathrm{~Hz})(\mathrm{ES}) \mathrm{m} / \mathrm{s}: \mathrm{C} 21 \mathrm{H} 24 \mathrm{BF} 2 \mathrm{~N} 2 \mathrm{O} 2$ : Calculated $[\mathrm{M}+\mathrm{H}]^{+} 385.1899$, actual $[\mathrm{M}+\mathrm{H}]^{+}$found 385.1911 .

3.2.3. Synthesis of tetramethyl-4,4-difluoro-4-bora-3a,4a-diazaindacene)methyl]phenoxy]ethyl (4-nitrophenyl) carbonate

To a solution of (3, Scheme 1) $(0.50 \mathrm{~g}, 1.30 \mathrm{mmol}, 1.0 \mathrm{eq})$ in dry DCM (15 mL) was added 4-nitrobenzyl chloroformate $(0.34 \mathrm{~g}, 1.69 \mathrm{mmol}, 1.3 \mathrm{eq})$ and TEA $(0.36 \mathrm{~mL}, 2.60 \mathrm{mmol}, 2.0 \mathrm{eq})$. The reaction mixture was left stirring for $2 \mathrm{~h}$ or until complete disappearance of the starting compound by TLC. The reaction mixture was concentrated and purified using biotage column chromatography (DCM/MeOH) $0-5 \%$ ) to yield $300.3 \mathrm{mg}$ (42\%) of PNP-BODIPY as orange needles. ${ }^{1} \mathrm{H} \mathrm{NMR}(400 \mathrm{MHz}$, $\left.\mathrm{CDCl}_{3}\right): \delta$ ppm $8.30(2 \mathrm{H}, \mathrm{d}, \mathrm{J}=9.2 \mathrm{~Hz}, \mathrm{Ar}), 7.42(2 \mathrm{H}, \mathrm{d}, \mathrm{J}=8.8 \mathrm{~Hz}, \mathrm{Ar}), 7.21(2 \mathrm{H}, \mathrm{d}, \mathrm{J}=8.4 \mathrm{~Hz}, \mathrm{Ar})$, $7.05(2 \mathrm{H}, \mathrm{d}, \mathrm{J}=8.4 \mathrm{~Hz}, \mathrm{Ar}), 5.98(2 \mathrm{H}, \mathrm{s}, 2 \times \mathrm{C}=\mathrm{CH}-\mathrm{C}), 4.69(2 \mathrm{H}, \mathrm{t}, \mathrm{J}=4.5 \mathrm{~Hz}, \mathrm{OCH} 2 \mathrm{CH} 2 \mathrm{OC}=\mathrm{O}), 4.34$ $(2 \mathrm{H}, \mathrm{t}, \mathrm{J}=4.5 \mathrm{~Hz}, \mathrm{OCH} 2 \mathrm{CH} 2 \mathrm{OC}=\mathrm{O}), 2.55(6 \mathrm{H}, \mathrm{s}, 2 \times \mathrm{CH}-\mathrm{C}-\mathrm{N}), 1.43(6 \mathrm{H}, \mathrm{s}, 2 \times \mathrm{CH}-\mathrm{C}=\mathrm{C}) .13 \mathrm{C} \mathrm{NMR}$ (125 MHz): $\delta$ ppm $158.70(\mathrm{O}=\mathrm{C}=\mathrm{O}), 155.5$ (Ar), 155.4 (Ar), 152.5 (Ar), 145.6 (Ar), 143.0 (Ar), 141.4 (Ar), 131.8 (Ar), 129.5 (Ar), 128.0 (Ar), 125.4 (Ar), 125.0 (Ar), 122.2 (Ar), 121.2 (2 × C=CH-C), 115.6 (Ar), 115.2 $(\mathrm{Ar}), 67.3(\mathrm{OCH} 2 \mathrm{CH} 2 \mathrm{OC}=\mathrm{O}), 65.5(\mathrm{OCH} 2 \mathrm{CH} 2 \mathrm{OC}=\mathrm{O}), 14.6(2 \times \mathrm{CH} 3 \mathrm{CN} \& 2 \times \mathrm{CH} 3 \mathrm{C}=\mathrm{C}) .{ }^{19} \mathrm{~F} \mathrm{NMR}$ (376MHz): $\delta-146.2(B-F 2, q, J=31.6 \mathrm{~Hz}),(\mathrm{ES}) \mathrm{m} / \mathrm{s}:$ C28H27BF2N3O6: Calculated $[\mathrm{M}+\mathrm{H}]^{+}$550.1950, actual $[\mathrm{M}+\mathrm{H}]^{+}$found 550.1947 .

\subsubsection{Synthesis of the Fluorescent Tobramycin Derivative (B) Used for Visualizing Bilayer Extraction}

Tobramycin (free base) (45 mg, $0.091 \mathrm{mmol}, 1.00 \mathrm{eq}$ ) was solubilized in anhydrous DMF $(5.0 \mathrm{~mL})$ with the assistance of gentle heating, then the solution was allowed to cool to room temperature. To the solution was added (4, Scheme 1) (50 mg, 0.095, $1.05 \mathrm{eq})$ and Hunig's base (44 $\mu \mathrm{L}, 0.364 \mathrm{mmol}, 4.0 \mathrm{eq})$ and left stirring overnight protected from light by a layer of aluminium foil. The reaction mixture was concentrated under high vacuum then purified using silica column chromatography using an eluent of $\left.\left(\mathrm{DCM} / \mathrm{MeOH} / \mathrm{NH}_{4} \mathrm{OH}\right) 6: 3: 1\right)$ to yield $13.6 \mathrm{mg}(17 \%)$ of the titled compound as an orange solid. ${ }^{1} \mathrm{H}$ NMR (400 MHz, D $\left.\mathrm{O}\right): \delta$ ppm $8.04(2 \mathrm{H}, \mathrm{d}, \mathrm{J}=8.5 \mathrm{~Hz}, \mathrm{Ar}), 7.42(1 \mathrm{H}), 7.2(1 \mathrm{H}), 7.0(2 \mathrm{H}), 6.84$ $(2 \mathrm{H}, \mathrm{d}, \mathrm{J}=8.5 \mathrm{~Hz}, \mathrm{Ar}), 6.74(2 \mathrm{H}), 5.78(2 \mathrm{H}), 5.39(2 \mathrm{H}), 4.21(2 \mathrm{H}), 4.06-3.15(17 \mathrm{H}, \mathrm{m}), 2.65(3 \mathrm{H}), 2.44$ (2H), 2.30-2.05 (6H, m), $1.86(2 \mathrm{H}), 1.62-1.31(4 \mathrm{H}, \mathrm{m}), 1.17-0.87(6 \mathrm{H}, \mathrm{m}), 0.72-0.56(3 \mathrm{H}, \mathrm{m}) .{ }^{19} \mathrm{~F} \mathrm{NMR}$ (376 MHz): $\delta-146.2\left(\mathrm{~B}-\mathrm{F}_{2}, \mathrm{q}, \mathrm{J}=32.0 \mathrm{~Hz}\right),(\mathrm{ES}) \mathrm{m} / \mathrm{s}: \mathrm{C}_{40} \mathrm{H}_{59} \mathrm{BN}_{7} \mathrm{O}_{12} \mathrm{~F}_{2}$ : Calculated $[\mathrm{M}+\mathrm{H}]^{+}$878.4305, actual $[\mathrm{M}+\mathrm{H}]^{+}$found 878.4283 .

\subsubsection{Visualization of the Extraction of the Fluorescent Tobramycin Derivative}

Stock solutions of fluorescent tobramycin $(1.5 \mathrm{mg} / \mathrm{mL})$ in deionized water and AOT $(7.1 \mathrm{mg} / \mathrm{mL})$ in DCM were prepared. The extraction of the fluorescent tobramycin derivative from the aqueous 
phase $(2 \mathrm{~mL})$ into the organic phase $(2 \mathrm{~mL})$ with/without AOT was assessed by mixing the phases together at $600 \mathrm{rpm}$ for $3 \mathrm{~h}$ after which the phases were separated by centrifugation at $4400 \mathrm{rpm}$ enabling visualization of the tobramycin in the aqueous or organic layer.

\subsection{Calculating the Main Physical Descriptors of Tobramycin Derivatives and AOT Complexes Thereof}

The physical descriptors (constitutional and electronic) of tobramycin and its AOT-complex were calculated. The selected descriptors were the total polar surface area, number of hydrogen bond donors, number of hydrogen bond acceptors, molecular globularity, molecular flexibility, LogP $(\mathrm{O} / \mathrm{W})$ and the molecular weight. The descriptors were calculated using MOE version 2014.0901 (Chemical Computing Group Inc., Montreal, Canada) after constructing the two investigated drugs utilising the builder tool in the same software to generate the 3D structures of the investigated drugs from their isomeric SMILES obtained from The PubChem Project ${ }^{\circledR}[48,49]$.

\subsection{Analytical Methodology for the Detection of Tobramycin}

Reagent A consisting of $80 \mathrm{mg}$ of ortho-phthaldialdehyde in $1 \mathrm{~mL}$ of $95 \%$ ethanol and reagent $\mathrm{B}$ containing $200 \mu \mathrm{L}$ of boric acid ( $\mathrm{pH}$ 9.7, $0.4 \mathrm{M}$ ), $400 \mu \mathrm{L} \beta$-mercaptoethanol and $200 \mu \mathrm{L}$ of diethyl ether were mixed. Serial dilutions of tobramycin were prepared in boric acid ( $\mathrm{pH} 9.7,0.4 \mathrm{M})$. One hundred $\mu \mathrm{L}$ of each tobramycin standard was added to $100 \mu \mathrm{L}$ of the reagent mixture. The plate was read by fluorescence spectroscopy at $\lambda_{\mathrm{ex}} 360 \mathrm{~nm}, \lambda_{\mathrm{em}} 460 \mathrm{~nm}$, respectively. The calibration curve is displayed in Figure S15.

\section{5. $W / O / W$ and $S / O / W$ Preparation of PLGA Nanoparticles Entrapping Tobramycin}

Tobramycin loaded PLGA nanoparticles were prepared through two separate methodologies. For the water in oil in water $(\mathrm{W} / \mathrm{O} / \mathrm{W})$ methodology, a primary emulsion was formed by dissolving $3 \mathrm{mg}$ of tobramycin in $0.5 \mathrm{~mL}$ of water followed by emulsification by sonication at 40 watts in $2 \mathrm{~mL}$ of DCM containing $50 \mathrm{mg}$ of PLGA RG502H or PLGA RG503. The resulting W/O emulsion was added to $10 \mathrm{~mL}$ of PVA (2.5\% in PBS buffer, $\mathrm{pH} 7.4$ ) followed by further sonication to form the final $\mathrm{W} / \mathrm{O} / \mathrm{W}$ emulsion. For the solid in oil in water $(\mathrm{S} / \mathrm{O} / \mathrm{W})$ methodology, $3 \mathrm{mg}$ of tobramycin was dissolved in $100 \mu \mathrm{L}$ of water and added to $2 \mathrm{~mL}$ of acetone containing $50 \mathrm{mg}$ of PLGA RG502H or 503. The resulting S/O phase was added to $10 \mathrm{~mL}$ of PVA ( $2.5 \%$ in $25 \mathrm{mM}$ PBS buffer) to form the final S/O/W formulation. Organic solvent was removed under vacuum at room temperature. Both formulations were centrifuged at 20,000 $\mathrm{g}$ and washed in PBS three times by centrifugation resuspension cycles. Results are presented as mean \pm S.D, $N=3$.

\subsection{Extraction of Tobramycin into Organic Solvents by AOT}

Stock solutions of tobramycin $(1.5 \mathrm{mg} / \mathrm{mL} \mathrm{pH} 4)$ and surfactant AOT $(7.1 \mathrm{mg} / \mathrm{mL})$ were prepared in double distilled water and a range of organic solvents respectively. Two $\mathrm{mL}$ of tobramycin stock solution was added to an equal volume of AOT stock solution in each of the organic solvents under study and the two solutions were mixed at $600 \mathrm{rpm}$ for $3 \mathrm{~h}$. The phases were separated by centrifugation at $4400 \mathrm{rpm}$ for $10 \mathrm{~min}$ and the aqueous phase was collected and monitored for the presence of tobramycin. The fluorescence intensity of the aqueous phase was monitored at $\lambda_{\mathrm{ex}} / \lambda_{\mathrm{em}} 360 / 460 \mathrm{~nm}$ and compared to a standard curve of tobramycin base including surfactant AOT at a concentration of $2 \mathrm{mg} / \mathrm{mL}$. Results are presented as mean $\pm \mathrm{S} . \mathrm{D}, \mathrm{N}=3$.

To assess the effect of molar ratio of AOT to tobramycin on the extraction process, the molar ratio of surfactant AOT to tobramycin was varied. A stock solution of tobramycin was prepared in double distilled water (DDW) $(1.5 \mathrm{mg} / \mathrm{mL}, \mathrm{pH} 4)$ and $2 \mathrm{~mL}$ was added to a stock solution of AOT in DCM at varying concentrations. The resultant suspension was stirred at $600 \mathrm{rpm}$ for $3 \mathrm{~h}$. The phases were separated by centrifugation at $4400 \mathrm{rpm}$ and the concentration of tobramycin in the aqueous phase was determined as described previously. Results are presented as mean $\pm S . D, N=3$. 
To assess the effect of formulation $\mathrm{pH}$ on the extraction process stock, solutions of tobramycin were prepared $(1.5 \mathrm{mg} / \mathrm{mL})$ and the $\mathrm{pH}$ was adjusted to $2,4,6,8,10$ and $12.2 \mathrm{~mL}$ of each stock solution of tobramycin was then added to $2 \mathrm{~mL}$ of surfactant AOT $(7.1 \mathrm{mg} / \mathrm{mL})$ in DCM. The solutions were mixed at $600 \mathrm{rpm}$ for $3 \mathrm{~h}$. The phases were separated by centrifugation at $4400 \mathrm{rpm}$ and the concentration of tobramycin in the aqueous phase was determined as described previously. Results are presented as mean \pm S.D, $N=3$.

\subsection{Preparation of PLGA Nanoparticles Loaded with Tobramycin-AOT Complexes}

Equal volumes of tobramycin base $(1.5 \mathrm{mg} / \mathrm{mL}$ in water adjusted to $\mathrm{pH} 4)$ and AOT $(7.1 \mathrm{mg} / \mathrm{mL}$ in dichloromethane) (1:5 molar ratio) were mixed by stirring for $3 \mathrm{~h}$ at $600 \mathrm{rpm}$ at room temperature. After incubation the aqueous and organic phases were separated by centrifugation for $5 \mathrm{~min}$ at $4400 \mathrm{rpm}$, and the dichloromethane removed by evaporation yielding a very viscous oil. Three mg of the viscous oil was dissolved in DCM (2 mL) with 10-50 mg of either PLGA RG502H or PLGA RG503. The DCM was added to $10 \mathrm{~mL}$ of PVA (2.5\% in PBS buffer $\mathrm{pH} 7.4$ ) followed by sonication at 40 watts to form an O/W emulsion. DCM was removed under vacuum at room temperature. Formulations were centrifuged at 20,000 $\mathrm{g}$ and washed with PBS three times by centrifugation-resuspension cycles. The amount of tobramycin entrapped in the nanoparticles was assessed by determination of the tobramycin content in the supernatant collected after nanoparticle formulation.

\subsection{Dynamic Light Scattering (DLS) and Zeta Potential Measurements}

DLS and zeta potential measurements were performed using a Malvern zetasizer (Nano ZS; Malvern instruments, Malvern, UK). Each sample was recorded in triplicate (10 runs each). The average of three separate samples was determined and are presented as mean \pm S.D, $N=3$.

\subsection{Release of Tobramycin from PLGA Nanoparticles Loaded with Tobramycin-AOT Complexes}

Drug release was quantified by incubating the nanoparticles in dialysis membranes with a $10,000 \mathrm{Da} \mathrm{MWCO}$ at $37^{\circ} \mathrm{C}$ under agitation. The release of the tobramycin was quantified by incubating $3 \mathrm{mg}$ of nanoparticles in $1 \mathrm{~mL}$ of PBS in the donor compartment with $5 \mathrm{~mL}$ of PBS in the receiver compartment. At each time point, the PBS solution was collected and replaced with fresh PBS release medium. The concentration of tobramycin in the aqueous phase was determined as described previously. Results are presented as mean \pm S.D, $N=3$.

\subsection{Antimicrobial Activity against P. aeruginosa}

Broth micro-dilution tests were performed according to NCCLS guidelines. Serial two-fold dilutions of tobramycin (from a stock solution which had been sterile filtered through a $0.22 \mu \mathrm{m}$ filter) in $100 \mu \mathrm{L}$ of Luria Bertani (LB) broth were performed on a 96-well plate in the range 0-25 $\mu \mathrm{g}$ tobramycin/mL for the drug loaded nanoparticles, free tobramycin and the blank nanoparticles as negative control. The actively growing cultures were diluted to an optical density reading of 0.3 $\left(\mathrm{A}_{550}\right)$ to give a starting inoculum of $2 \times 10^{5} \mathrm{CFU} / \mathrm{mL}$. One hundred $\mu \mathrm{L}$ of the starting inoculum $\left(2 \times 10^{5} \mathrm{CFU} / \mathrm{mL}\right)$ was added to each well of the plate and incubated aerobically at $37^{\circ} \mathrm{C}$ for $24 \mathrm{~h}$. Following incubation, the cell viability was determined by reading the plate absorbance at $550 \mathrm{~nm}$. Results are presented as mean \pm S.D, $N=3$.

\subsection{Statistical Analysis}

Data was analysed with Graphpad Prism (San Diego, CA, USA). Experiments were performed in triplicate and the mean value reported \pm S.D. 


\section{Conclusions}

There is a market need for the development of drug delivery systems and sustained release of polar antimicrobials capable of eradicating bacterial growth in patients with weak immune system [62-68]. Here we describe one method of loading high levels of antimicrobials in PLGA nanoparticles and demonstrate their efficacy against $P$. aeruginosa in vitro, using transient drug-polymer interactions for encapsulation and slow-release.

Supplementary Materials: The following are available online at http://www.mdpi.com/2079-4983/10/ 2/26/s1, Figure S1: ${ }^{1} \mathrm{H}$ NMR of 4-(2-hydroxyethoxy)benzaldehyde (2). Figure S2: ${ }^{13} \mathrm{C}$ NMR of 4-(2-hydroxyethoxy)benzaldehyde (2). Figure S3: ${ }^{1} \mathrm{H}$ NMR of (3) (3, 5-dimethyl-1H-pyrrol-2-yl)-(tetramethyl-4, 4-difluoro-4-bora-3a, 4a-diaza-indacene) methyl] phenoxy] ethanol. Figure S4: ${ }^{13} \mathrm{C}$ NMR of (3) (3, 5-dimethyl-1H-pyrrol-2-yl)-(tetramethyl-4, 4-difluoro-4-bora-3a, 4a-diaza-indacene) methyl] phenoxy] ethanol. Figure S5: ${ }^{19} \mathrm{~F}$ NMR of (3) (3, 5-dimethyl-1H-pyrrol-2-yl)-(tetramethyl-4, 4-difluoro-4-bora-3a, 4a-diaza-indacene) methyl] phenoxy] ethanol. Figure S6: ${ }^{1} \mathrm{H}$ NMR of (4) tetramethyl-4,4-difluoro-4-bora-3a,4a-diazaindacene)methyl]phenoxy]ethyl (4-nitrophenyl) carbonate. Figure S7: ${ }^{13} \mathrm{C}$ NMR of (4) tetramethyl-4,4-difluoro-4-bora-3a,4a-diazaindacene)methyl]phenoxy]ethyl (4-nitrophenyl) carbonate. Figure S8: ${ }^{19} \mathrm{~F}$ NMR of (4) tetramethyl-4,4-difluoro-4-bora-3a,4a-diazaindacene)methyl]phenoxy]ethyl (4-nitrophenyl) carbonate. Figure S9: ${ }^{19}$ F NMR of (4) tetramethyl-4,4-difluoro-4-bora-3a,4a-diazaindacene)methyl] phenoxy]ethyl (4-nitrophenyl) carbonate. Figure S10: ${ }^{1} \mathrm{H}$ NMR of the fluorescent tobramycin derivative (B). Figure S11: Mass spectrometry data for the fluorescent tobramycin derivative (B). Figure S12: Mass spectrometry data for the fluorescent tobramycin derivative (B). Figure S13: Elemental composition report for the fluorescent tobramycin derivative (B). Figure S14: Effect of the molar ratio of AOT:tobramycin on the extraction of tobramycin into dichloromethane. Figure S15: Tobramycin calibration curve in the absence/presence of AOT.

Author Contributions: Conceptualization, M.E.M.; methodology, M.H.; R.N.C.; R.M.H.; C.J.; J.G.H.; M.E.M.; formal analysis, M.H.; R.N.C.; R.M.H.; C.J.; J.G.H.; M.E.M.; investigation, M.H.; R.N.C.; R.M.H.; C.J.; J.G.H.; M.E.M.; data curation, M.E.M.; writing-original draft preparation, M.H. and J.G.H.; writing-review and editing, M.H.; R.N.C.; R.M.H.; C.J.; J.G.H.; M.E.M.; supervision, M.E.M.; project administration, M.E.M.; funding acquisition, M.E.M.

Funding: This research was supported by: a PhD studentship from Queen's University Belfast for M.H., R.N.C. and C.J.; the Faculty of Pharmacy at Ain Shams University for support of R.M.H.; Lancaster University for a Faculty of Science and Technology Early Career Internal Grant to support R.M.H. and J.G.H.; the UK Engineering and Physical Sciences Research Council (EPSRC, EP/H031065/1) to support M.E.M.

Acknowledgments: We thank Faisal Hayat and Mikail Makarov at the University of South Alabama for administrative support with data management planning and realisation.

Conflicts of Interest: The authors declare no conflict of interest. The funders had no role in the design of the study; in the collection, analyses, or interpretation of data; in the writing of the manuscript, or in the decision to publish the results.

\section{References}

1. Janam, R.; Gulati, A.K.; Nath, G. Antibiogram and genotyping of Pseudomonas aeruginosa isolated from human, animal, plant, water and soil sources in north India. Southeast Asian J. Trop. Med. Public Health 2011, 42, 1477-1488. [PubMed]

2. Bassetti, M.; Vena, A.; Croxatto, A.; Righi, E.; Guery, B. How to manage Pseudomonas aeruginosa infections. Drugs Context 2018, 7, 212527. [CrossRef] [PubMed]

3. Kassavin, D.S.; Pascarella, L.; Goldfarb, M.A. Surgical site infections: incidence and trends at a community teaching hospital. Am. J. Surg. 2011, 201, 749-753. [CrossRef] [PubMed]

4. Mendelson, M.H.; Gurtman, A.; Szabo, S.; Neibart, E.; Meyers, B.R.; Policar, M.; Reddy, S. Pseudomonas aeruginosa bacteremia in patients with AIDS. Clin. Infect. Dis. 1994, 18, 886-895. [CrossRef] [PubMed]

5. Govan, J.R.; Deretic, V. Microbial pathogenesis in cystic fibrosis: Mucoid Pseudomonas aeruginosa and Burkholderia cepacia. Microbiol. Rev. 1996, 60, 539-574.

6. Van Delden, C.; Iglewski, B.H. Cell-to-cell signaling and Pseudomonas aeruginosa infections. Emerg. Infect. Dis. 1998, 4, 551-560. [CrossRef] [PubMed]

7. Corvaisier, S.; Maire, P.H.; Bouvier d'Yvoire, M.Y.; Barbaut, X.; Bleyzac, N.; Jelliffe, R.W. Comparisons between antimicrobial pharmacodynamic indices and bacterial killing as described by using the Zhi model. Antimicrob. Agents Chemother. 1998, 42, 1731-1737. [CrossRef] 
8. Gelperina, S.; Kisich, K.; Iseman, M.D.; Heifets, L. The potential advantages of nanoparticle drug delivery systems in chemotherapy of tuberculosis. Am. J. Respir. Crit. Care Med. 2009, 172, 1487-1490. [CrossRef]

9. Sanchez, G.; Cuellar, D.; Zulantay, I.; Gajardo, M.; González-Martin, G. Cytotoxicity and trypanocidal activity of nifurtimox encapsulated in ethylcyanoacrylate nanoparticles. Biol. Res. 2002, 35, 39-45. [CrossRef]

10. Youssef, M.; Fattal, E.; Alonso, M.J.; Roblot-Treupel, L.; Sauzières, J.; Tancrède, C.; Andremont, A. Effectiveness of nanoparticle-bound ampicillin in the treatment of Listeria monocytogenes infection in athymic nude mice. Antimicrob. Agents Chemother. 1988, 32, 1204-1207. [CrossRef]

11. Wang, H.; Yu, J.; Lu, X.; He, X. Nanoparticle systems reduce systemic toxicity in cancer treatment. Nanomedicine 2016, 11, 103-106. [CrossRef] [PubMed]

12. Khadka, P.; Ro, J.; Kim, H.; Kim, I.; Kim, J.T.; Kim, H.; Lee, J. Pharmaceutical particle technologies: An approach to improve drug solubility, dissolution and bioavailability. AJPS 2014, 9, 304-316. [CrossRef]

13. Shen, S.; Wu, Y.; Liu, Y.; Wu, D. High drug-loading nanomedicines: progress, current status, and prospects. Int. J. Nanomed. 2017, 12, 4085-4109. [CrossRef] [PubMed]

14. Alexis, F.; Pridgen, E.M.; Langer, R.; Farokhzad, O.C. Nanoparticle technologies for cancer therapy. Handb. Exp. Pharmacol. 2010, 197, 55-86.

15. Vij, N. Synthesis and evaluation of airway targeted PLGA nanoparticles for drug delivery in obstructive lung diseases. Methods Mol. Biol. 2010, 906, 303-310.

16. Minyahil, A.; Woldu, J.L.L. Nanoparticles and the new era in diabetes management. Int. J. Basic Clin. Pharmacol. 2014, 3, 277-284.

17. Pinto-Alphandary, H.; Andremont, A.; Couvreur, P. Targeted delivery of antibiotics using liposomes and nanoparticles: research and applications. Int. J. Antimicrob. Agents 2000, 13, 155-168. [CrossRef]

18. Yang, S.C.; Lu, L.F.; Cai, Y.; Zhu, J.B.; Liang, B.W.; Yang, C.Z. Body distribution in mice of intravenously injected camptothecin solid lipid nanoparticles and targeting effect on brain. J. Control. Release 1999, 59, 299-307. [CrossRef]

19. Hanberger, H.; Edlund, C.; Furebring, M.; Giske, C.G.; Melhus, A.; Nilsson, L.E.; Eliasson, E.; Scand, J. Rational use of aminoglycosides-Review and recommendations by the Swedish Reference Group for Antibiotics (SRGA). Infect. Dis. 2013, 45, 161-175. [CrossRef]

20. Krause, K.M.; Serio, A.W.; Kane, T.R.; Connolly, L.E. Aminoglycosides: An Overview. Cold Spring Harb. Perspect. Med. 2016, 6, a027029. [CrossRef]

21. Schassan, H.H. Antimicrobial effectiveness of sisomicin. I: In vitro activity of sisomicin compared with gentamicin, tobramycin, amikacin and kanamycin. Infection 1976, 4, 35-41. [CrossRef]

22. Le Goffic, F.; Capmau, M.L.; Tangy, F.; Baillarge, M. Mechanism of action of aminoglycoside antibiotics. Binding studies of tobramycin and its $6^{\prime}-\mathrm{N}$-acetyl derivative to the bacterial ribosome and its subunits. Eur. J. Biochem. 1979, 102, 73-81. [CrossRef]

23. Shi, K.; Caldwell, S.J.; Fong, D.H.; Berghuis, A.M. Prospects for circumventing aminoglycoside kinase mediated antibiotic resistance. Front. Cell Infect. Microbiol. 2013, 23, 22. [CrossRef]

24. Ramirez, M.S.; Tolmasky, M.E. Aminoglycoside modifying enzymes. Drug Resist. Updat. 2010, 13, 151-171. [CrossRef]

25. Mingeot-Leclercq, M.-P.; Glupczynski, Y.; Tulkens, P.M. Aminoglycosides: Activity and resistance. Antimicrob. Agents Chemother. 1999, 43, 727-737. [CrossRef]

26. Lecaroz, C.; Gamazo, C.; Blanco-Prieto, M.J. Nanocarriers with gentamicin to treat intracellular pathogens. J. Nanosci. Nanotechnol. 2006, 6, 3296-3302. [CrossRef]

27. Prior, S.; Gamazo, C.; Irache, J.M.; Merkle, H.P.; Gander, B. Gentamicin encapsulation in PLA/PLGA microspheres in view of treating Brucella infections. Int. J. Pharm. 2000, 196, 115-125. [CrossRef]

28. Thote, A.J.; Gupta, R.B. Formation of nanoparticles of a hydrophilic drug using supercritical carbon dioxide and microencapsulation for sustained release. Nanomed. NBM 2005, 1, 85-90. [CrossRef]

29. Türk, M.; Upper, G.; Hils, P. Formation of composite drug-polymer particles by co-precipitation during the rapid expansion of supercritical fluids. J. Supercrit. Fluid. 2006, 39, 253-263. [CrossRef]

30. Makadia, H.K.; Siegel, S.J. Poly Lactic-co-Glycolic Acid (PLGA) as Biodegradable Controlled Drug Delivery Carrier. Polymers 2011, 3, 1377-1397. [CrossRef]

31. Danhier, F.; Ansorena, E.; Silva, J.M.; Coco, R.; Le Breton, A.; Préat, V. PLGA-based nanoparticles: An overview of biomedical applications. J. Control. Release 2012, 161, 505-522. [CrossRef] 
32. Hines, D.J.; Kaplan, D.L. Poly(lactic-co-glycolic) acid-controlled-release systems: Experimental and modeling insights. Crit. Rev. Ther. Drug Carrier Syst. 2013, 30, 257-276. [CrossRef]

33. Lecaroz, M.C.; Blanco-Prieto, M.J.; Campanero, M.A.; Salman, H.; Gamazo, C. Poly(D,L-lactide-coglycolide) particles containing gentamicin: pharmacokinetics and pharmacodynamics in Brucella melitensis-infected mice. Antimicrob. Agents Chemother. 2007, 51, 1185-1190. [CrossRef]

34. Abdelghany, S.M.; Quinn, D.J.; Ingram, R.J.; Gilmore, B.F.; Donnelly, R.F.; Taggart, C.C.; Scott, C. Gentamicin-loaded nanoparticles show improved antimicrobial effects towards Pseudomonas aeruginosa infection. Int. J. Nanomed. 2012, 7, 4053-4063.

35. Namazi, H.; Adeli, M. Dendrimers of citric acid and poly (ethylene glycol) as the new drug-delivery agents. Biomaterials 2005, 26, 1175-1183. [CrossRef]

36. Gaudana, R.; Parenky, A.; Vaishya, R.; Samanta, S.K.; Mitra, A.K. Development and characterization of nanoparticulate formulation of a water soluble prodrug of dexamethasone by HIP complexation. J. Microencapsul. 2011, 28, 10-20. [CrossRef]

37. Trivedi, R.; Kompella, U.B. Nanomicellar formulations for sustained drug delivery: Strategies and underlying principles. Nanomed. Lond. 2010, 5, 485-505. [CrossRef]

38. Marier, J.F.; Brazier, J.L.; Lavigne, J.; Ducharme, M.P. Liposomal tobramycin against pulmonary infections of Pseudomonas aeruginosa: A pharmacokinetic and efficacy study following single and multiple intratracheal administrations in rats. Antimicrob. Chemother. 2003, 52, 247-252. [CrossRef]

39. Assil, K.K.; Frucht-Perry, J.; Ziegler, E.; Schanzlin, D.J.; Schneiderman, T.; Weinreb, R.N. Tobramycin liposomes. Single subconjunctival therapy of pseudomonal keratitis. Invest. Ophthalmol. Vis. Sci. 1991, 32, 3216-3220.

40. Beaulac, C.; Clement-Major, S.; Hawari, J.; Lagace, J. Eradication of mucoid Pseudomonas aeruginosa with fluid liposome-encapsulated tobramycin in an animal model of chronic pulmonary infection. Antimicrob. Agents Chemother. 1996, 40, 665-669. [CrossRef]

41. Johnsson, M.; Edwards, K. Liposomes, disks, and spherical micelles: aggregate structure in mixtures of gel phase phosphatidylcholines and poly(ethylene glycol)-phospholipids. Biophys. J. 2003, 85, 3839-3847. [CrossRef]

42. Halwani, M.; Mugabe, C.; Azghani, A.O.; Lafrenie, R.M.; Kumar, A.; Omri, A. Bactericidal efficacy of liposomal aminoglycosides against Burkholderia cenocepacia. Antimicrob. Chemother. 2007, 60, 760-769. [CrossRef]

43. Holmkvist, A.D.; Friberg, A.; Nilsson, U.J.; Schouenborg, J. Hydrophobic ion pairing of a minocycline/ $\mathrm{Ca}(2+) / A O T$ complex for preparation of drug-loaded PLGA nanoparticles with improved sustained release. Int. J. Pharmaceut. 2016, 499, 351-357. [CrossRef]

44. Osakai, T.; Shinohara, A. Electrochemical aspects of the reverse micelle extraction of proteins. Anal. Sci. 2008, 24, 901-906. [CrossRef]

45. Lye, G.J.; Asenjo, J.A.; Pyle, D.L. Extraction of lysozyme and ribonuclease-a using reverse micelles: Limits to protein solubilization. Biotechnol. Bioeng. 1995, 47, 509-519. [CrossRef]

46. Mohd-Setapar, S.H.; Mohamad-Aziz, S.N. Backward Extraction of Penicillin G Using AOT Reverse Micelles. Adv. Sci. Lett. 2013, 19, 3688-3694. [CrossRef]

47. Nucci, N.V.; Pometun, M.S.; Wand, A.J. Site-resolved measurement of water-protein interactions by solution NMR. Nat. Struct. Mol. Biol. 2011, 18, 245-249. [CrossRef]

48. Hathout, R.M.; Metwally, A.A. Towards better modelling of drug-loading in solid lipid nanoparticles: Molecular dynamics, docking experiments and Gaussian Processes machine learning. Eur. J. Pharm. Biopharm. 2016, 108, 262-268. [CrossRef]

49. Shah, S.A.A.; Firlak, M.; Berrow, S.R.; Halcovitch, N.R.; Baldock, S.J.; Yousafzai, B.M.; Hathout, R.M.; Hardy, J.G. Electrochemically Enhanced Drug Delivery Using Polypyrrole Films. Materials 2018, 11, 1123. [CrossRef]

50. Han, F.Y.; Thurecht, K.J.; Whittaker, A.K.; Smith, M.T. Bioerodable PLGA-Based Microparticles for Producing Sustained-Release Drug Formulations and Strategies for Improving Drug Loading. Front. Pharmacol. 2016, 7, 185. [CrossRef]

51. Brzeziński, M.; Socka, M.; Kost, B. Microfluidics for producing polylactide nanoparticles and microparticles and their drug delivery application. Polym. Int. 2018. [CrossRef] 
52. Hong, X.; Wei, L.; Ma, L.; Chen, Y.; Liu, Z.; Yuan, W. Novel preparation method for sustained-release PLGA microspheres using water-in-oil-in-hydrophilic-oil-in-water emulsion. Int. J. Nanomed. 2013, 8, 2433-2441.

53. Toorisaka, E.; Watanabe, K.; Hirata, M. Development of Fine Poly(D,L-Lactic-Co-Glycolic Acid) Particles for Hydrophilic Drug Using a Solid-in-Oil-in-Water Emulsion. J. Encaps. Ads. Sci. 2018, 8, 58-66. [CrossRef]

54. Imbuluzqueta, E.; Elizondo, E.; Gamazo, C.; Moreno-Calvo, E.; Veciana, J.; Ventosa, N.; Blanco-Prieto, M.J. Novel bioactive hydrophobic gentamicin carriers for the treatment of intracellular bacterial infections. Acta Biomater. 2011, 7, 1599-1608. [CrossRef] [PubMed]

55. Ter Boo, G.A.; Grijpma, D.W.; Richards, R.G.; Moriarty, T.F.; Eglin, D. Preparation of gentamicin dioctyl sulfosuccinate loaded poly(trimethylene carbonate) matrices intended for the treatment of orthopaedic infections. Clin. Hemorheol. Microcirc. 2015, 60, 89-98. [CrossRef] [PubMed]

56. Elizondo, E.; Sala, S.; Imbuluzqueta, E.; González, D.; Blanco-Prieto, M.J.; Gamazo, C.; Veciana, J. High loading of gentamicin in bioadhesive PVM/MA nanostructured microparticles using compressed carbon-dioxide. Pharm. Res. 2011, 28, 309-321. [CrossRef] [PubMed]

57. Benson, J.R.; Hare, P.E. O-phthalaldehyde: fluorogenic detection of primary amines in the picomole range. Comparison with fluorescamine and ninhydrin. Proc. Natl. Acad. Sci. USA 1975, 72, 619-622. [CrossRef] [PubMed]

58. Vineeth, P.; Rao Vadaparthi, P.R.; Kumar, K.; Babu, B.D.J.; Rao, A.V.; Babu, K.S. Stability Indicating Chiral HPLC method for the estimation of Zaltoprofen enatiomers in pharmaceutical formulations. Int. J. Pharm. Pharm. Sci. 2014, 6, 638-645.

59. Metwally, A.A.; Hathout, R.M. Computer-Assisted Drug Formulation Design: Novel Approach in Drug Delivery. Mol. Pharm. 2015, 12, 2800-2810. [CrossRef] [PubMed]

60. Metwally, A.A.; El-Ahmady, S.H.; Hathout, R.M. Selecting optimum protein nano-carriers for natural polyphenols using chemoinformatics tools. Phytomedicine 2016, 23, 1764-1770. [CrossRef]

61. Mehanny, M.; Hathout, R.M.; Geneidi, A.S.; Mansour, S. Studying the effect of physically-adsorbed coating polymers on the cytotoxic activity of optimized bisdemethoxycurcumin loaded-PLGA nanoparticles. J. Biomed. Mater. Res. A 2017, 105, 1433-1445. [CrossRef] [PubMed]

62. Kemme, M.; Heinzel-Wieland, R. Quantitative Assessment of Antimicrobial Activity of PLGA Films Loaded with 4-Hexylresorcinol. J. Funct. Biomater. 2018, 9, 4. [CrossRef] [PubMed]

63. Quiram, G.; Montagner, F.; Palmer, K.L.; Stefan, M.C.; Washington, K.E.; Rodrigues, D.C. Novel Chlorhexidine-Loaded Polymeric Nanoparticles for Root Canal Treatment. J. Funct. Biomater. 2018, 9, 29. [CrossRef] [PubMed]

64. Harris, M.; Ahmed, H.; Pace, L.; Minter, J.; Neel, M.; Jennings, J. Evaluation of Antibiotic-Releasing Triphasic Bone Void Filler In-Vitro. J. Funct. Biomater. 2018, 9, 55. [CrossRef] [PubMed]

65. Kenawy, E.-R.; Abdel-Hay, F.; El-Newehy, M.; Ottenbrite, R.M. Effect of $\mathrm{pH}$ on the drug release rate from a new polymer-drug conjugate system. Polym. Int. 2008, 57, 85-91.

66. Neumann, K.; Lilienkampf, A.; Bradley, M. Responsive polymeric nanoparticles for controlled drug delivery. Polym. Int. 2017, 66, 1756-1764. [CrossRef]

67. Hernandez-Soria, A.; Yang, X.; Grosso, M.J.; Reinhart, J.; Ricciardi, B.F.; Bostrom, M. In vitro elution characteristics of antibiotic laden BoneSource ${ }^{\mathrm{TM}}$, hydroxyapatite bone cement. J. Biomater. Sci. Polym. Ed. 2013, 24, 797-806. [CrossRef]

68. Hafeman, A.E.; Zienkiewicz, K.J.; Carney, E.; Litzner, B.; Stratton, C.; Wenke, J.C.; Guelcher, S.A. Local delivery of tobramycin from injectable biodegradable polyurethane scaffolds. J. Biomater. Sci. Polym. Ed. 2010, 21, 95-112. [CrossRef]

69. Bhatt, P.; Lalani, R.; Vhora, I.; Patil, S.; Amrutiya, J.; Misra, A.; Mashru, R. Liposomes encapsulating native and cyclodextrin enclosed paclitaxel: Enhanced loading efficiency and its pharmacokinetic evaluation. Int. J. Pharm. 2018, 536, 95-107. [CrossRef]

70. Patel, J.; Amrutiya, J.; Bhatt, P.; Javia, A.; Jain, M.; Misra, A. Targeted delivery of monoclonal antibody conjugated docetaxel loaded PLGA nanoparticles into EGFR overexpressed lung tumour cells. J. Microencapsul. 2018, 35, 204-217. [CrossRef]

(C) 2019 by the authors. Licensee MDPI, Basel, Switzerland. This article is an open access article distributed under the terms and conditions of the Creative Commons Attribution (CC BY) license (http://creativecommons.org/licenses/by/4.0/). 